\title{
Asian economies lead increase in carbon dioxide emissions
}

[LONDON] Global carbon dioxide emissions from the burning of fossil fuels continued to increase throughout 1996, according to statistics compiled by the London-based World Energy Council (WEC). The highest percentage rises came from the Asia-Pacific region, including India, China and the newly industrializing 'tiger' economies, as well as the Middle East.

The statistics will inevitably strengthen calls from the United States for the industrializing countries to be included in a proposed legally binding treaty to reduce carbon dioxide emissions. The treaty, due to be negotiated in Kyoto, Japan, in December, is aimed at reducing the impact of man-made global warming.

Carbon dioxide emissions in North America increased by 3 per cent last year to 1.76 billion tonnes of carbon (the increase from 1994 to 1995 was less than 1 per cent). The rising emissions are likely to strengthen pressure on the United States to sign up to clear reduction targets.

But emissions also increased in the European Union (EU), which for the first time since 1992 failed to maintain carbon dioxide emissions below 1990 levels. This will strengthen American scepticism of an EU pledge to reduce emissions by 15 per cent by 2010 .
At the end of 1996, says the report, global emissions of carbon dioxide stood at 6.5 billion tonnes - 6.4 per cent higher than in 1990 and 2.7 per cent higher than in 1995.

The WEC, whose members represent national energy industries, compiled its report from data provided by governments and energy companies on emissions from three fossil fuel sources: coal (2.4 billion tonnes of carbon), oil (2.8 billion tonnes), and natural gas (1.3 billion tonnes).

The Asia-Pacific region - excluding Japan, Australia and New Zealand registered a 37 per cent increase in emissions from 1990. They now stand at just over 1.5 billion tonnes a year, up 5.5 per cent from 1995.

In sharp contrast, emissions from eastern Europe continued to decline, although the 2.5 per cent drop from 1995 to 900 million tonnes was much smaller than in previous years. Emissions in some countries, notably the Czech Republic, Poland, Hungary and Romania, have begun to rise again.

After three consecutive years of falling emissions up to 1994, EU countries recorded their second successive increase - the first time the 1990 threshold had been crossed. At the end of 1996, the EU's 15 member countries together were emitting 957 million tonnes of carbon a year, 0.8 per

\section{Technology programme thinks small}

[WASHINGTON] The Clinton administration is planning extensive reforms to its controversial Advanced Technology Program (ATP). These are planned to end years of partisan battles over the programme which provides federal support for civilian technology developments. William Daley, the Secretary of Commerce, announced last week that ATP would be remodelled to support joint research projects involving two or more companies. It will provide more support for small companies and less for large ones, and will create new links between its projects and the state governments in the regions where they take place.

The wide-ranging reforms are designed to meet criticisms of the programme made by Republicans in the Congress. Since the Republicans won control of the Congress in 1995, ATP has been the main point of disagreement about science and technology policy between the Congress and the Clinton White House.

Many observers believe that ATP would be more palatable to Republicans if it were to concentrate on small companies and integrate itself with local industrial interests, so that projects would, for example, clearly help batches of auto-component makers in Michigan, or clusters of biotechnology companies in Houston, Texas.

Earlier this year, Lewis Branscomb - a former IBM executive and director of the then National Bureau of Standards, who now heads a Science, Technology and Public Policy programme at Harvard University produced a report recommending many of the changes now being proposed by Daley.

When President Bill Clinton was first elected in 1992, he pledged to build ATP into a billion-dollar-a-year programme. But Republicans branded it an inappropriate involvement by the government in private-sector activities and sought to eliminate it. As a result the programme has survived on funding of around $\$ 250$ million a year, with fierce clashes each year on its funding level.

\begin{tabular}{|c|c|c|c|c|c|}
\hline \multicolumn{6}{|c|}{ Global carbon dioxide emissions } \\
\hline \multirow[b]{2}{*}{ U.S. } & \multirow{2}{*}{$\begin{array}{r}90 \\
918\end{array}$} & \multirow{2}{*}{ ‘95 } & \multirow{2}{*}{$\begin{array}{r}96 \\
1759\end{array}$} & \multicolumn{2}{|c|}{$\begin{array}{c}{ }^{9} 90-96 \text { '95-96 } \\
\% \text { change }\end{array}$} \\
\hline & & & & +8.7 & +3.1 \\
\hline Asia-Pacific & 1126 & 1465 & 1546 & +37 & +5.5 \\
\hline France & 112.6 & 109.4 & 111.0 & -1.6 & +1.5 \\
\hline German & 281.9 & 254.7 & 260.1 & -7.8 & +2.1 \\
\hline & 120.9 & 121.8 & 121.9 & +0.8 & +0.1 \\
\hline U.K. & 170.0 & 163.5 & 168.3 & -1.0 & +2.9 \\
\hline EU Total & 949 & 936 & 957 & +0.8 & +2.3 \\
\hline
\end{tabular}

Figures in millions of tonnes of carbon

cent higher than in 1990.

Most of the additional emissions came from Germany, the United Kingdom and Denmark, widely considered to be three of Europe's most environmentally conscious countries. Michael Jefferson, the WEC's deputy secretary general, believes that, for Germany and the United Kingdom at least, the 'honeymoon' caused by the shutdown of polluting industries now seems to be over.

According to Jefferson, the statistics suggest that emissions may be on the rise. But British government officials disagree, saying the increase is within predicted forecasts and of no particular significance.

There is, however, little doubt that the statistics will be a setback to Europe's efforts to seize the moral high ground in the race to slow down man-made global warming. They may also fuel doubts about the United Kingdom's ability to meet its even more ambitious promise of a 20 per cent reduction in carbon dioxide emissions.

After falling every year from 1991, Britain's emissions jumped by nearly 5 million tonnes of carbon last year, according to the WEC. This was caused partly by an increase in the use of domestic heating fuel during the colder than average winter. Another contributory factor was the United Kingdom's higher than expected economic growth, which accelerated sharply last autumn to between 3.5 and 4.5 per cent per year. The government expects economic growth to remain high this year, falling off to 2.5 per cent in 1998 .

Government officials say these latest statistics are entirely within their own forecasts, which predict carbon dioxide emissions will drop by 1 million tonnes between 1995 and 2000.

The British government recently outlined how it planned to reduce carbon dioxide emissions. It includes raising the proportion of electricity from renewable sources to 10 per cent, reducing road traffic and operating a comprehensive household energy efficiency initiative. EhsanMasood 